\title{
Genetic parameters for fertility of dairy heifers and cows at different parities and relationships with production traits in first lactation
}

\author{
F. Tiezzi, ${ }^{\star}$ C. Maltecca,† A. Cecchinato, ${ }^{*}$ M. Penasa, ${ }^{* 1}$ and G. Bittante ${ }^{\star}$ \\ *Department of Agronomy, Food, Natural resources, Animals and Environment, University of Padova, Viale dell'Università 16, \\ 35020 Legnaro (PD), Italy \\ †Department of Animal Science, North Carolina State University, Raleigh 27695
}

\begin{abstract}
The objectives of this study were to estimate genetic parameters for fertility of Brown Swiss cattle, considering reproductive measures in different parities as different traits, and to estimate relationships between production traits of first lactation and fertility of heifers and first-parity and second-parity cows. Reproductive indicators were interval from parturition to first service, interval from first service to conception, interval from parturition to conception, number of inseminations to conception, conception rate at first service, and nonreturn rate at $56 \mathrm{~d}$ after first service. Production traits were peak milk yield (pMY), lactation milk yield, and lactation length (LL). Data included 37,546 records on heifers, and 24,098 and 15,653 records on first- and second-parity cows, respectively. Cows were reared in 2,035 herds, calved from 1999 to 2007, and were progeny of 527 AI bulls. Gibbs sampling was implemented to obtain (co)variance components using both univariate and bivariate threshold and censored linear sire models. Estimates of heritability for reproductive traits in heifers (0.016 to 0.026$)$ were lower than those in first-parity (0.017 to 0.142) and second-parity (0.026 to 0.115$)$ cows. Genetic correlations for fertility in first- and second-parity cows were very high $(>0.920)$, whereas those between heifers and lactating cows were moderate (0.348 to 0.709$)$. The latter result indicates that fertility in heifers is a different trait than fertility in lactating cows, and hence it cannot be used as robust indicator of cow fertility. Heifer fertility was not related to production traits in first lactation (genetic correlations between -0.215 and 0.251). Peak milk yield exerted a moderate and unfavorable effect on the interval from parturition to first service (genetic correlations of 0.414 and 0.353 after first and second calving, respectively), and a low and unfavorable effect on other fertility traits (genetic correlations between -0.281 and 0.295). Infertility after first calving caused a strong
\end{abstract}

Received May 26, 2012.

Accepted August 30, 2012.

${ }^{1}$ Corresponding author: mauro.penasa@unipd.it elongation of the lactation, and LL was negatively correlated with fertility of cows after second calving, so that LL can itself be regarded as a measure of fertility. Lactation milk yield depends on both pMY and LL, and, as such, is a cause and consequence of (in)fertility. Key words: heifer, dairy cow, fertility and production, genetic parameter

\section{INTRODUCTION}

Female fertility has become a major breeding goal in the dairy cattle industry, and several measures of reproductive fitness have been included in merit indices worldwide (VanRaden et al., 2004; Andersen-Ranberg et al., 2005; Miglior et al., 2005). Fertility can be evaluated by considering it as the same trait over the parities of a given animal (Berry et al., 2003; González-Recio et al., 2006; König et al., 2008) or by treating reproductive performance over parities as different traits (Hansen et al., 1983; Bagnato and Oltenacu, 1993; de Jong, 1998; Andersen-Ranberg et al., 2005). In the latter approach, differences in the physiological status of virgin heifers compared with lactating cows are assumed, and factors affecting fertility are supposed to be of different magnitude over lactations. Previous studies reported estimates of heritability for reproductive performance that did not differ consistently over parities (Muir et al., 2004; Holtsmark et al., 2008; Zink et al., 2011). However, results on genetic correlations for the same fertility trait on virgin heifers and first-lactation cows are controversial. Mäntysaari and Van Vleck (1989), Raheja et al. (1989a), and Oltenacu et al. (1991) found this genetic correlation to be approximately null; Hodel et al. (1995), Muir et al. (2004), and Andersen-Ranberg et al. (2005) found it to be medium to low; and Jamrozik et al. (2005), Gredler et al. (2007), Holtsmark et al. (2008) and Liu et al. (2008) found it to be medium to high.

The genetic antagonism between fertility and simultaneous production is well known (Veerkamp et al., 2001; Pryce et al., 2002; Banos and Coffey, 2010), whereas less information is available on the relationship between 
reproductive performance of heifers and production traits at first parity. Hansen et al. (1983), Mäntysaari and Van Vleck (1989), and Oltenacu et al. (1991) found that genetic correlations between heifer fertility and first-parity milk yield were not significantly different from zero. Similarly, Andersen-Ranberg et al. (2005) and Holtsmark et al. (2008) estimated a null genetic correlation between heifer fertility and first-lactation protein yield. However, Muir et al. (2004) reported a stronger relationship between heifer fertility and production of first-lactation cows than between first-parity fertility and contemporary production.

From a practical point of view, the choice of considering fertility as the same trait or as different traits over parities for its inclusion in merit indices is not trivial. Heifer fertility data are available earlier in life and offer an evaluation of reproductive performance not biased by milk production. On the other hand, fertility of lactating cows is the trait that has declined substantially (Andersen-Ranberg et al., 2005; Hare et al., 2006) and reflects the real ability of the cow to conceive when milk yield hinders reproductive physiology.

The aims of this study were to estimate genetic parameters for several fertility traits in Brown Swiss cows considering reproductive performance in different parities as different traits, and to estimate relationships between various production traits of first lactation and fertility of heifers, first-parity cows, and second-parity cows.

\section{MATERIALS AND METHODS}

\section{Data Collection and Editing Procedure}

Insemination and production records on Brown Swiss cows were obtained from the Breeders Association of Bolzano-Bozen Province (Italy). Data were from cows that calved from 1999 to 2007 and that were progeny of 527 AI bulls (for full details, see Tiezzi et al., 2011). Fertility measures were available for virgin heifers $(\mathrm{n}=$ $37,546)$ and first-parity $(\mathrm{n}=24,098)$ and second-parity $(\mathrm{n}=15,653)$ cows distributed in 2,035 herds. Animals with records in a given parity were required to have records in all previous parities, heifer status included. Moreover, animals were required to have had all their productive life within the same herd. Fertility traits for first- and second-parity cows were interval from parturition to first service (iPF), interval from first service to conception (iFC), interval from parturition to conception (iPC), number of inseminations to conception (INS), conception rate at first service (CFS), and nonreturn rate at $56 \mathrm{~d}$ after first service (NR56). For virgin heifers, the same traits were considered except for iPF and iPC. Interval from parturition to first service and iPC were restricted to be between 21 and $400 \mathrm{~d}$, and iFC to be between 0 and $400 \mathrm{~d}$. Herds with fewer than 3 cows in first lactation were discarded. Sires were required to have a minimum of 5 daughters with first-parity records, distributed across at least 3 herds.

Interval traits were treated as linear Gaussian variables, whereas INS was coded as an ordinal categorical variable ( 5 classes) according to the number of services needed to achieve pregnancy (inseminations occurring within $6 \mathrm{~d}$ were considered as a single service). Conception rate at first service and NR56 were coded as dichotomous categorical variables according to the achievement of pregnancy at first service for CFS, or the occurrence of a second breeding within $56 \mathrm{~d}$ after first service (0) or not (1) for NR56.

Fertility records that were lacking following calving (e.g., inseminations on first lactation not followed by a second calving of the cow) were considered censored for iFC and iPC and handled via a data augmentation algorithm. For INS, a penalty was added to the recorded number of inseminations if the subsequent parity was missing or more than 4 services were performed, following the approach of Hou et al. (2009) for days open. The genetic analyses for INS were performed only on the penalized trait.

Besides measures of fertility, production traits from first-parity cows were also available; namely, peak milk yield (pMY, kg), lactation milk yield (IMY, $\mathrm{kg}$ ), and lactation length (LL, d).

\section{Statistical Analyses}

Univariate Models. Estimates of variance components for within-parity fertility traits were obtained under a single-trait approach. The univariate censored linear and threshold analyses were performed for Gaussian and dichotomous categorical variables, respectively, according to the following models:

$$
\mathbf{y}=\mathbf{X} \boldsymbol{\beta}+\mathbf{Z}_{\mathrm{h}} \mathbf{h}+\mathbf{Z}_{\mathrm{s}} \mathbf{s}+\mathbf{e}
$$

and

$$
\boldsymbol{\lambda}=\mathbf{X} \boldsymbol{\beta}+\mathbf{Z}_{\mathrm{h}} \mathbf{h}+\mathbf{Z}_{\mathrm{s}} \mathbf{s}+\mathbf{Z}_{\mathrm{ss}} \mathbf{S S}+\mathbf{Z}_{\mathrm{t}} \mathbf{t}+\mathbf{e},
$$

where $\mathbf{y}$ is the vector of observations for linear traits (iPF, iFC, iPC, pMY, IMY, and LL); $\boldsymbol{\lambda}$ is the vector of unobserved liabilities for the dichotomous categorical traits (CFS and NR56); $\boldsymbol{\beta}$ is the vector of systematic effects (specific to each class of traits); $\mathbf{h}$ is the vector of random effects for herds; $\mathbf{s}$ is the vector of random genetic effects for sires of cows; ss is the vector of random effects for service sires; $\mathbf{t}$ is the vector of random effects for technicians; e is the vector of random residuals; and 
$\mathbf{X}, \mathbf{Z}_{\mathrm{h}}, \mathbf{Z}_{\mathrm{s}}, \mathbf{Z}_{\mathrm{ss}}$, and $\mathbf{Z}_{\mathrm{t}}$ are incidence matrices relating the corresponding effects to the dependent variable. The ordinal categorical variable (INS) was analyzed under a censored threshold model, including the same effects considered for Gaussian traits. Systematic effects were year-month of first calving for pMY, lMY, and LL; year-month of calving of the respective parity for $\mathrm{iPF}$ and $\mathrm{iPC}$; and the respective year-month of first insemination for iFC, INS, CFS and NR56.

For linear variables, censored records were handled via data augmentation (Tanner and Wong, 1987; Guo et al., 2001), so that the linear model can be written as follows:

$$
y_{c} \sim N\left(\mathbf{X} \boldsymbol{\beta}+\mathbf{Z}_{\mathrm{h}, \mathrm{c}} \mathbf{h}+\mathbf{Z}_{\mathrm{s}, \mathrm{c}} \mathbf{s}, \sigma_{c}^{2}\right) I\left(y_{c}, \infty\right),
$$

where $y_{c}$ is the value (augmented over the observed) assumed for every censored record and $I$ is an indicator variable that assumes value 1 if the record is censored, 0 otherwise. Under this condition, censored records were augmented over the observed according to the variance components estimated on the previous iterations and, being right-censored, the simulated value fell between the observed $\left(y_{c}\right)$ and $\infty$.

For categorical variables with multinomial sampling (INS), the probability function was

$$
\begin{gathered}
\operatorname{Prob}\left(y_{i}=j \mid \boldsymbol{\beta}, \mathbf{h}, \mathbf{s}, \mathbf{T}\right)=\Phi\left[\mathrm{T}_{j}-\left(\mathbf{X} \boldsymbol{\beta}+\mathbf{Z}_{\mathrm{h}, \mathrm{i}} \mathbf{h}+\mathbf{Z}_{\mathrm{s}, \mathrm{s}} \mathbf{s}\right)\right] \\
-\Phi\left[\mathrm{T}_{j-1}-\left(\mathbf{X} \boldsymbol{\beta}+\mathbf{Z}_{\mathrm{h}, \mathrm{i}} \mathbf{h}+\mathbf{Z}_{\mathrm{s}, \mathbf{i}}\right)\right],
\end{gathered}
$$

where $i$ is the $i$ th observation, $j$ is the threshold to which the observation belongs, $\Phi($.$) is the standard$ cumulative normal distribution function, and $\mathrm{T}$ are the unknown thresholds assuming that $-\infty=\mathrm{T}_{0} \leq$ $\mathrm{T}_{1} \leq \mathrm{T}_{2} \leq \mathrm{T}_{\mathrm{j}}=\infty$. The unobserved liability for the $y_{i}=j$ observation fell between the thresholds $j$ and the threshold $j-1$. In the analysis of INS, thresholds were sampled at every iteration of the Gibbs sampler, whereas no sampling occurred in the analysis of the binary variables (CFS and NR56), as these traits have only a single threshold, which was fixed to 0 .

Bivariate Models. Bivariate analyses were used to investigate the genetic relationship between fertility measures recorded on different parities, and between fertility and production traits. (Co)variance components were obtained fitting linear-linear, thresholdlinear, and threshold-threshold sire models. Systematic and random effects were identical to the univariate approach.

Model Assumptions. Gibbs sampling was implemented in a Bayesian framework. Bounded uniform priors were used for all systematic effects, and null means and normal univariate or bivariate prior distributions for sire (s), herd (h), service sire (ss), and technician (t) random effects were assumed. In matrix notation,

$$
\begin{gathered}
{\left[\begin{array}{l}
\mathbf{s}_{\mathbf{1}} \\
\mathbf{s}_{\mathbf{2}}
\end{array}\right] \sim N(0, \mathbf{G} \otimes \mathbf{A}),} \\
{\left[\begin{array}{l}
\mathbf{h}_{\mathbf{1}} \\
\mathbf{h}_{\mathbf{2}}
\end{array}\right] \sim N(0, \mathbf{H} \otimes \mathbf{I}),} \\
{\left[\begin{array}{l}
\mathbf{s s}_{\mathbf{1}} \\
\mathbf{s s}_{\mathbf{2}}
\end{array}\right] \sim N(0, \mathbf{S S} \otimes \mathbf{I}),} \\
{\left[\begin{array}{l}
\mathbf{t}_{\mathbf{1}} \\
\mathbf{t}_{\mathbf{2}}
\end{array}\right] \sim N(0, \mathbf{T} \otimes \mathbf{I}),}
\end{gathered}
$$

where

$$
\mathbf{G}\left[\begin{array}{cc}
\sigma_{s 1}^{2} & \sigma_{s 12} \\
\sigma_{s 21} & \sigma_{s 2}^{2}
\end{array}\right]
$$

is the $2 \times 2$ sire (co)variance matrix, $\mathbf{A}$ is the numerator relationship matrix between sires,

$$
\mathbf{H}\left[\begin{array}{cc}
\sigma_{h 1}^{2} & \sigma_{h 12} \\
\sigma_{h 21} & \sigma_{h 2}^{2}
\end{array}\right]
$$

is the herd (co)variance matrix, and $\mathbf{I}$ is an identity matrix. Service sire and technician effects were parity specific. In bivariate analyses, these effects were fitted on a single trait, leading to a notable simplification of the covariance structure. Thus, we had

$$
\mathbf{S S}\left[\begin{array}{cc}
\sigma_{s s 1}^{2} & 0 \\
0 & 0
\end{array}\right]
$$

for the service sire covariance matrix, and

$$
\mathbf{T}\left[\begin{array}{cc}
\sigma_{t 1}^{2} & 0 \\
0 & 0
\end{array}\right]
$$

for the technician covariance matrix.

Residuals were assumed correlated and normally distributed:

$$
\left[\begin{array}{l}
\mathbf{e}_{\mathbf{1}} \\
\mathbf{e}_{\mathbf{2}}
\end{array}\right] \sim N(0, \mathbf{R} \otimes \mathbf{I})
$$

where 


$$
\mathbf{R}\left[\begin{array}{cc}
\sigma_{e 1}^{2} & \sigma_{e 12} \\
\sigma_{e 21} & \sigma_{e 2}^{2}
\end{array}\right]
$$

is the residual (co)variance matrix for the linear-linear analyses and threshold-threshold analyses for INS. For threshold analyses on dichotomous traits (CFS and NR56), the residual variance was fixed to 1 . The residual (co)variance matrix with one linear and one threshold trait became

$$
\mathbf{R}=\left[\begin{array}{cc}
1 & \sigma_{e 12} \\
\sigma_{e 21} & \sigma_{e 2}^{2}
\end{array}\right],
$$

while we assumed that

$$
\mathbf{R}=\left[\begin{array}{ll}
1 & 0 \\
0 & 1
\end{array}\right]
$$

for the threshold-threshold analyses with 2 dichotomous traits, because in this case the residual covariance was fixed to zero, following the approach of Heringstad et al. (2004) on clinical mastitis.

For univariate models, a single Gibbs chain of 250,000 samples was obtained, whereas for bivariate models, 550,000 iterations were run. In all cases, the first 50,000 samples were discarded as burn-in. Samples were stored every 20 iterations for univariate and every 50 iterations for bivariate models, to leave 10,000 samples for inferences. The posterior mean was used as a point estimate of the (co)variance component and the related parameter.

Heritability $\left(h^{2}\right)$ was computed as follows:

$$
h^{2}=\frac{4 \sigma_{s}^{2}}{\sigma_{s}^{2}+\sigma_{h}^{2}+\sigma_{s s}^{2}+\sigma_{t}^{2}+\sigma_{e}^{2}},
$$

where $\sigma_{s}^{2}$ is the sire variance, $\sigma_{h}^{2}$ is the herd variance, $\sigma_{s s}^{2}$ is the service sire variance, $\sigma_{t}^{2}$ is the technician variance, and $\sigma_{e}^{2}$ is the residual variance. Genetic correlations $\left(\rho_{g}\right)$ were calculated as

$$
\rho_{g}=\frac{\operatorname{cov}_{s}(x, y)}{\sigma_{s, x} \sigma_{s, y}} .
$$

where $\operatorname{cov}_{s}(x, y)$ is the sire additive genetic covariance between traits $x$ and $y$, and $\sigma_{s, x}$ and $\sigma_{s, y}$ are the respective additive genetic standard deviations. All the computations in the present work were performed using the TM software (Legarra et al., 2008).

\section{RESULTS AND DISCUSSION}

\section{Descriptive Statistics}

Virgin heifers showed better reproductive performance than first- and second-parity cows (Table 1). Number of inseminations to conception, CFS, and NR56, respectively, averaged $1.56,0.65$, and 0.79 for heifers, $1.75,0.55$, and 0.71 for first-lactation cows, and $1.72,0.56$, and 0.71 for second-lactation cows. The average INS calculated on the penalized trait was 1.73, 1.93, and 1.94 for heifers and first- and second-parity cows, respectively (Table 1 ). Regarding iFC, the difference over parities was small but in favor of virgin heifers. The iPF and iPC were very similar in first- and second-lactation cows. Approximately $12 \%$ of heifers did not have information on first calving, and more than 13 and $17 \%$ of first- and second-lactation cows did not have information on second and third calvings, respectively (Table 1). Lactation milk yield averaged $6,794 \mathrm{~kg}$, and this reflected the national value reported for the Italian Brown Swiss cattle undergoing test-day milk recording (AIA, 2010).

\section{Heritability and Genetic Correlations Among Fertility Traits}

Estimates of heritability for iFC, INS, CFS, and NR56 were comparable between first- and secondlactation cows, whereas they showed the lowest values for heifers (Table 2). The most relevant differences between virgin heifers and first- and second-lactation cows were found for iFC, with estimates of 0.017, 0.039, and 0.029 , respectively, and for INS, with estimates of $0.026,0.046$, and 0.045 , respectively. Heritabilities for CFS and NR56 did not differ significantly over parities (Table 2). For the 2 interval traits measurable on lactating cows (iPF and $\mathrm{iPC}$ ), heritabilities were higher for first- than for second-parity animals (iPF: 0.142 and 0.115, and iPC: 0.093 and 0.050 for first- and secondparity cows, respectively), although significance was found only for iPC.

Estimates of heritability for iPC were higher than those reported for calving interval by Dal Zotto et al. (2005, 2007) on Brown Swiss cows, and for fertility traits of the same breed reared in tropical conditions (Estrada-León et al., 2008; Pérez and Gómez, 2009; Utrera et al., 2010). Hodel et al. (1995), using data from Simmental cattle in Switzerland, reported estimates of heritability for nonreturn rate at $90 \mathrm{~d}$ after first service that were higher in first-lactation cows (0.021 to 0.034) than in heifers (0.011 to 0.020), and Jamrozik et al. (2005), in Canadian Holstein cattle, estimated heritabilities, in first parity and in second and later parities, 
Table 1. Descriptive statistics of fertility and production traits over parities

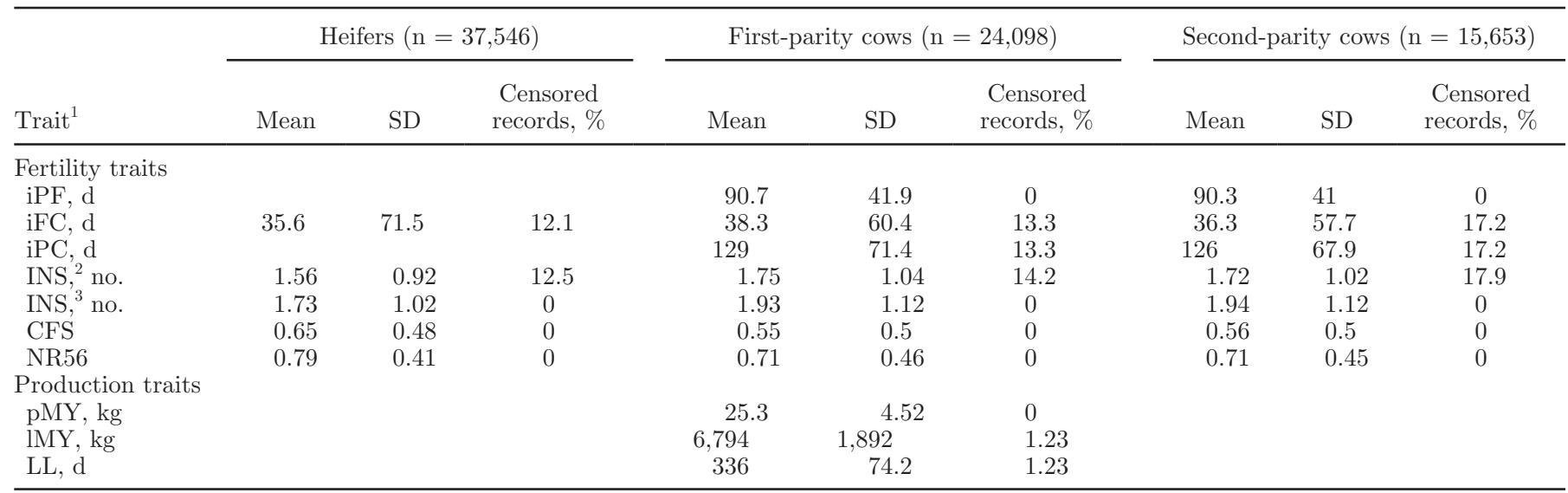

${ }^{1} \mathrm{iPF}=$ interval from parturition to first service; $\mathrm{iFC}=$ interval from first service to conception; iPC = interval from parturition to conception; INS = number of inseminations to conception; CFS = conception rate at first service; NR56 = nonreturn rate at $56 \mathrm{~d}$ after first service; pMY $=$ peak milk yield; lMY = lactation milk yield; LL = lactation length

${ }^{2}$ Actual number of inseminations to conception.

${ }^{3} \mathrm{~A}$ one-service penalty was added to cows that did not show calving after last insemination.

respectively, of 0.029 and 0.040 for NR56, 0.029 and 0.069 for INS, and 0.030 and 0.070 for iFC. Muir et al. (2004) obtained heritabilities of 0.030 and 0.040 for NR56 in Canadian Holstein heifers and primiparous cows, respectively. Andersen-Ranberg et al. (2005), Gredler et al. (2007), Holtsmark et al. (2008), and Liu et al. (2008) reported very low estimates of heritability for NR56 for both heifers and first-lactation cows (0.0096 to 0.022). Comparing estimates of heritability for fertility traits in first- and second-parity cows, neither Mitchell et al. (2005) on US Holsteins nor Raheja et al. (1989b) on Canadian Holsteins found differences.

Genetic correlations assessed by treating reproductive performance at different parities as different traits are given in Table 3. The highest estimates were obtained between first- and second-lactation cows, with values between 0.925 (INS) and 0.985 (iPC). These results suggest that fertility measured in subsequent lactations can be regarded as the same trait. Jansen (1986) reported moderate to high genetic correlations between fertility in different lactations, whereas Raheja et al. (1989b) estimated very low genetic relationships between fertility in first and second lactations.

Genetic correlations between heifers and first-lactation cows were of medium magnitude, and ranged from 0.348 (CFS) to 0.551 (iFC; Table 3). For CFS and NR56, zero was included within the $95 \%$ highest probability interval. The correlation between heifers and first-lactation cows for iFC (0.551) was close to findings of Liu et al. (2008) on German Holsteins (0.480), higher than that of Hodel et al. (1995) on Swiss Simmentals (0.370), and lower than that of Jamrozik et al. (2005) on Canadian Holsteins (0.760). For INS, Jamrozik et al. (2005) estimated a genetic correlation of 0.740 between heifers and first-lactation cows, whereas the value assessed by Gredler et al. (2007) on German and

Table 2. Estimates ${ }^{1}$ of heritability for fertility traits on heifers, first-parity cows, and second-parity cows

\begin{tabular}{|c|c|c|c|c|c|c|}
\hline Trait $^{2}$ & \multicolumn{2}{|c|}{ Heifers } & \multicolumn{2}{|c|}{ First-parity cows } & \multicolumn{2}{|c|}{ Second-parity cows } \\
\hline iPC & & & $0.093^{\mathrm{B}}$ & $0.062 ; 0.132$ & $0.050^{\mathrm{A}}$ & $0.026 ; 0.084$ \\
\hline INS & $0.026^{\mathrm{a}}$ & $0.015 ; 0.041$ & $0.046^{\mathrm{b}}$ & $0.027 ; 0.071$ & $0.045^{\mathrm{b}}$ & $0.023 ; 0.075$ \\
\hline CFS & 0.020 & $0.009 ; 0.037$ & 0.030 & $0.013 ; 0.054$ & 0.032 & $0.012 ; 0.061$ \\
\hline
\end{tabular}

${ }^{1}$ Estimates are the means of the marginal posterior densities for the heritability. Significance is given according to the difference between the distributions of the same trait over parities (lowercase letters for the difference being non-null at 90\%, uppercase letters for the difference being non-null at 95\%); HPD95 is the highest posterior density region at $95 \%$.

${ }^{2} \mathrm{iPF}=$ interval from parturition to first service; $\mathrm{iFC}=$ interval from first service to conception; iPC $=$ interval from parturition to conception; INS $=$ number of inseminations to conception; CFS $=$ conception rate at first service; NR56 = nonreturn rate at $56 \mathrm{~d}$ after first service. 
Table 3. Estimates ${ }^{1}$ of genetic correlations between reproductive performance treated as different trait in different parities

\begin{tabular}{|c|c|c|c|c|c|c|}
\hline Trait $^{2}$ & \multicolumn{2}{|c|}{ Heifers - first-parity cows } & \multicolumn{2}{|c|}{ Heifers - second-parity cows } & \multicolumn{2}{|c|}{ First-parity - second-parity cows } \\
\hline iPF & & & & & $0.984^{(4)}$ & $0.941 ; 0.999$ \\
\hline iPC & & & & & $0.985^{(5)}$ & $0.934 ; 0.999$ \\
\hline INS & $0.510^{(100)}$ & $0.210 ; 0.741$ & $0.646^{(100)}$ & $0.360 ; 0.850$ & $0.925^{(47)}$ & $0.689 ; 0.998$ \\
\hline CFS & $0.348^{(100)}$ & $-0.124 ; 0.733$ & $0.637^{(98)}$ & $0.217 ; 0.940$ & $0.967^{(21)}$ & $0.813 ; 0.999$ \\
\hline
\end{tabular}

${ }^{1}$ Estimates are the means of the marginal posterior densities for the genetic correlation. The value within parentheses is the probability of having samples with value lower than 0.95; HPD95 is the highest posterior density region at $95 \%$.

${ }^{2} \mathrm{iPF}=$ interval from parturition to first service; $\mathrm{iFC}=$ interval from first service to conception; iPC $=$ interval from parturition to conception; INS $=$ number of inseminations to conception; CFS $=$ conception rate at first service; NR56 = nonreturn rate at $56 \mathrm{~d}$ after first service.

Austrian Simmental was slightly lower (0.680). Both studies reported higher values than our results $(0.510)$, but the statistical approach was different: Jamrozik et al. (2005) and Gredler et al. (2007) used linear models for the analysis of INS, whereas we used a threshold model. The estimate for NR56 (0.349; Table 3) was higher than that (0.220) of Muir et al. (2004) on Canadian Holsteins using linear models, whereas the value assessed by Holtsmark et al. (2008) on Norwegian Red using a threshold analysis was notably higher (0.610). For the same trait, Andersen-Ranberg et al. (2005), Gredler et al. (2007), and Liu et al. (2008) estimated values higher than 0.500 through linear models.

Genetic correlations between heifers and secondlactation cows ranged from 0.636 (NR56) to 0.709 (iFC; Table 3) and were intermediate between estimates for heifers and first-lactation animals, and estimates for first- and second-lactation animals.

Overall, genetic relationships far from unity between heifers and lactating cows suggest that fertility is indeed a different trait when measured on heifers and cows. The interpretation of this result is that, given a pool of genes affecting the overall fertility of an individual, the expression of genes in the virgin heifer might be different from that in a lactating cow.

\section{Relationships Between Fertility and Production Traits}

Heritabilities for pMY, lMY, and LL recorded on first-lactation cows were 0.130 (lower and upper bound of the $95 \%$ highest posterior density region: 0.099 to 0.166 ), 0.118 (lower and upper bound of the $95 \%$ highest posterior density region: 0.089 to 0.153 ), and 0.052 (lower and upper bound of the 95\% highest posterior density region: 0.032 to 0.077 ), respectively (data not shown). These values are similar to those found by Cecchinato et al. (2011) in Italian Brown Swiss.
Genetic correlations between production traits recorded in first-lactation cows and reproductive performance measured in heifers and in first- and secondparity cows are shown in Table 4 . The relationship between production and contemporary fertility followed the pattern of a recent study by Tiezzi et al. (2011) in the same population. Peak milk yield, which can be regarded as the moment of major productive load of the cow at the time of insemination, showed a low to moderate and unfavorable relationship to reproductive traits. The highest correlation (0.414) was estimated with iPF, meaning that cows producing high amounts of milk at peak may have delayed first estrous or that farmers voluntarily delayed the beginning of the breeding period. The genetic relationships between pMY and the other fertility traits were low and ranged from -0.250 with NR56 to 0.275 with iPC (Table 4). Lactation length showed high and unfavorable correlations with iPF (0.877), iFC (0.895), iPC (0.933), INS (0.810), and CFS $(-0.822)$, and a moderate and unfavorable relationship with NR56 ( -0.467 ; Table 4$)$. The high estimates of genetic correlations between LL and reproductive performance confirm that lactation elongation is mainly a consequence of low fertility, also because the elongation of calving interval depends more on LL than on the dry period (Gallo et al., 2008). Lactation milk yield, which mainly depends on pMY (cause of infertility) and LL (consequence of infertility), was moderately related to contemporary fertility, exhibiting unfavorable values with interval traits (0.493 to 0.617), INS (0.472), CFS (-0.553), and NR56 (-0.439; Table 4).

Genetic correlations between fertility of heifers and production traits of first-parity cows were low, with estimates between -0.215 and 0.251 (Table 4), suggesting that potentially high-producing females are not predisposed to be genetically infertile, but rather factors associated with high production moderately affect fertility. This is in agreement with Hodel et al. (1995), who found production of Swiss Simmental cows in first 
Table 4. Estimates ${ }^{1}$ of genetic correlations between production traits measured on first-lactation cows and reproductive traits measured on heifers, first-parity, and second-parity cows

\begin{tabular}{|c|c|c|c|c|}
\hline $\begin{array}{l}\text { Fertility } \\
\text { trait }^{2}\end{array}$ & $\begin{array}{l}\text { Production trait } \\
\text { (first parity) }\end{array}$ & Heifers & First-parity cows & Second-parity cows \\
\hline \multirow[t]{2}{*}{$\mathrm{iPF}$} & Peak milk yield & & $0.414^{(100)}$ & $0.353^{(100)}$ \\
\hline & Lactation milk yield & & $0.617^{(100)}$ & $0.465^{(100)}$ \\
\hline \multirow{3}{*}{$\mathrm{iFC}$} & Peak milk yield & $-0.128^{(81)}$ & $0.214^{(95)}$ & $0.293^{(96)}$ \\
\hline & Lactation milk yield & $-0.083^{(72)}$ & $0.493^{(100)}$ & $0.487^{(100)}$ \\
\hline & Lactation length & $0.251^{(93)}$ & $0.895^{(100)}$ & $0.794^{(100)}$ \\
\hline \multirow[t]{3}{*}{ INS } & Peak milk yield & $-0.099^{(77)}$ & $0.204^{(94)}$ & $0.249^{(94)}$ \\
\hline & Lactation milk yield & $-0.023^{(56)}$ & $0.472^{(100)}$ & $0.428^{(100)}$ \\
\hline & Lactation length & $0.213^{(91)}$ & $0.810^{(100)}$ & $0.616^{(100)}$ \\
\hline \multirow[t]{3}{*}{ CFS } & Peak milk yield & $0.000^{(50)}$ & $-0.142^{(79)}$ & $-0.281^{(93)}$ \\
\hline & Lactation milk yield & $-0.153^{(82)}$ & $-0.553^{(100)}$ & $-0.514^{(100)}$ \\
\hline & Lactation length & $-0.215^{(86)}$ & $-0.822^{(100)}$ & $-0.657^{(100)}$ \\
\hline
\end{tabular}

${ }^{1}$ Estimates are the means of the marginal posterior densities for the genetic correlation, with the probability of having samples of sign concordant to the mean within parentheses.

${ }^{2} \mathrm{iPF}=$ interval from parturition to first service; $\mathrm{iFC}=$ interval from first service to conception; iPC $=$ interval from parturition to conception; $\mathrm{INS}=$ number of inseminations to conception; CFS $=$ conception rate at first service; NR56 = nonreturn rate at $56 \mathrm{~d}$ after first service.

lactation to be more strongly related to contemporary than to heifer reproductive performance $(0.690$ and 0.240 for interval from first to last service, and -0.580 and -0.210 for nonreturn rate at $90 \mathrm{~d}$ after first service). In a study on Norwegian Red cattle, AndersenRanberg et al. (2005) reported genetic correlations of 0.040 between $305-\mathrm{d}$ protein yield of first-lactation cows and heifer fertility, and -0.180 between 305 -d protein yield and fertility of first-parity cows. Holtsmark et al. (2008), in the same breed, reported genetic correlations of -0.070 between $305-d$ protein yield of first-lactation cows and heifer fertility, and -0.240 between $305-\mathrm{d}$ protein yield and fertility of first-parity cows.

Genetic correlations between pMY in first lactation and reproductive performance after the second calving were low and ranged from -0.281 to 0.353 (Table 4), very similar to those estimated on the contemporary lactation; that is, after first calving. The genetic influence of IMY and LL measured during first lactation on fertility traits recorded after second calving was lower than that estimated on fertility traits recorded after first calving. Comparison with other studies was not possible, because we are not aware of estimates of genetic correlations currently available in the literature between production traits of first-lactation cows and fertility of later parities.

\section{CONCLUSIONS}

Although fertility measured on first- and secondparity cows can be regarded as the same trait, the moderate genetic correlations between reproductive performance recorded in heifers and lactating cows suggest that fertility is indeed a different trait when evaluated in heifers and producing animals. Consequently, heifer fertility cannot be used as a robust indicator of cow fertility. It is likely that the metabolic demand to support high milk yield leads to depressed reproductive performance and makes the reproductive physiology of lactating cows different from that of heifers. Peak milk yield is an indicator of production level during the early service period and was demonstrated to have a moderate to low correlation with contemporary fertility traits. Lactation length is highly and unfavorably related to fertility. Lactation milk yield depends on both pMY (cause of infertility) and LL (consequence of infertility) and it is moderately associated with fertility traits. In conclusion, high pMY causes a moderate impairment of fertility (delayed first service, lower conception rate, and repeated services), infertility causes a strong elongation of the lactation, and both determine an increase of lMY from infertile cows.

\section{ACKNOWLEDGMENTS}

Authors thank the Trento Province (Italy) for financial support, the Breeders Association of BolzanoBozen province (Italy) for providing field data, the Italian Brown Swiss Cattle Breeders Association (ANARB, Verona, Italy) for supplying pedigree information, and the Superbrown Consortium of Bolzano and Trento, and Trento Province (Italy) for technical support. 


\section{REFERENCES}

AIA (Italian Breeders Association). 2010. National production statistics. Accessed Jan. 20, 2012. http://www.aia.it/aia-website/it/ attivita.

Andersen-Ranberg, I. M., G. Klemetsdal, B. Heringstad, and T. Steine. 2005. Heritabilities, genetic correlations, and genetic change for female fertility and protein yield in Norwegian dairy cattle. J. Dairy Sci. 88:348-355

Bagnato, A., and P. A. Oltenacu. 1993. Genetic study of fertility traits and production in different parities in Italian Friesian cattle. J. Anim. Breed. Genet. 110:126-134.

Banos, G., and M. P. Coffey. 2010. Genetic association between body energy measured throughout lactation and fertility in dairy cattle. Animal 4:189-199.

Berry, D. P., F. Buckley, P. Dillon, R. D. Evans, M. Rath, and R. F. Veerkamp. 2003. Genetic relationships among body condition score, body weight, milk yield, and fertility in dairy cows. J. Dairy Sci. 86:2193-2204.

Cecchinato, A., M. Penasa, M. De Marchi, L. Gallo, G. Bittante, and P. Carnier. 2011. Genetic parameters of coagulation properties, milk yield, quality, and acidity estimated using coagulating and noncoagulating milk information in Brown Swiss and HolsteinFriesian cows. J. Dairy Sci. 94:4205-4213.

Dal Zotto, R., P. Carnier, L. Gallo, G. Bittante, and M. Cassandro. 2005. Genetic relationship between body condition score, fertility, type and production traits in Brown Swiss dairy cows. Ital. J. Anim. Sci. 4(Suppl. 3):30-32.

Dal Zotto, R., M. De Marchi, C. Dalvit, M. Cassandro, L. Gallo, P. Carnier, and G. Bittante. 2007. Heritabilities and genetic correlations of body condition score and calving interval with yield, somatic cell score, and linear type traits in Brown Swiss cattle. J. Dairy Sci. 90:5737-5743.

de Jong, G. 1998. Index for daughters' fertility in the Netherlands. Interbull Bull. 18:102-105.

Estrada-León, R. J., J. G. Magana, and J. C. Segura-Correa. 2008. Genetic parameters for reproductive traits of Brown Swiss cows in the tropics of Mexico. J. Anim. Vet. Adv. 7:124-129.

Gallo, L., B. Contiero, M. De Marchi, P. Carnier, M. Cassandro, and G. Bittante. 2008. Retrospective analysis of dry period length in Italian Holstein cows. Ital. J. Anim. Sci. 7:65-76.

González-Recio, O., R. Alenda, Y. M. Chang, K. A. Weigel, and D. Gianola. 2006. Selection for female fertility using censored fertility traits and investigation of the relationship with milk production. J. Dairy Sci. 89:4438-4444.

Gredler, B., C. Fürst, and J. Sölkner. 2007. Analysis of new fertility traits for the joint genetic evaluation in Austria and Germany Interbull Bull. 37:152-155.

Guo, S. F., D. Gianola, R. Rekaya, and T. Short. 2001. Bayesian analysis of lifetime performance in Landrace sows using a linear mixed model with censoring. Livest. Prod. Sci. 72:243-252.

Hansen, L. B., A. E. Freeman, and P. J. Berger. 1983. Association of heifer fertility with cow fertility and yield in dairy cattle. J. Dairy Sci. 66:306-314.

Hare, E., H. D. Norman, and J. R. Wright. 2006. Trends in calving ages and calving intervals for dairy cattle breeds in the United States. J. Dairy Sci. 89:365-370.

Heringstad, B., Y. M. Chang, D. Gianola, and G. Klemetsdal. 2004 Multivariate threshold model analysis of clinical mastitis in multiparous Norwegian dairy cattle. J. Dairy Sci. 87:3038-3046.

Hodel, F., J. Moll, and N. Kuenzi. 1995. Analysis of fertility in Swiss Simmental cattle: Genetic and environmental effects on female fertility. Livest. Prod. Sci. 41:95-103.

Holtsmark, M., B. Heringstad, P. Madsen, and J. Ødegård. 2008. Genetic relationship between culling, milk production, fertility and health traits in Norwegian Red cows. J. Dairy Sci. 91:4006-4012.

Hou, Y., P. Madsen, R. Labouriau, Y. Zhang, M. S. Lund, and G. Su. 2009. Genetic analysis of days from calving to first insemination and days open in Danish Holsteins using different models and censoring scenarios. J. Dairy Sci. 92:1229-1239.

Jamrozik, J., J. Fatehi, G. J. Kistemaker, and L. R. Schaeffer. 2005. Estimates of genetic parameters for Canadian Holstein female reproduction traits. J. Dairy Sci. 88:2199-2208.

Jansen, J. 1986. Studies on fertility in dairy cattle, based on analysis of AI data. PhD Thesis. Agric. Univ., Wageningen, the Netherlands.

König, S., Y. M. Chang, U. U. v. Borstel, D. Gianola, and H. Simianer. 2008. Genetic and phenotypic relationships among milk urea nitrogen, fertility, and milk yield in Holstein cows. J. Dairy Sci. 91:4372-4382

Legarra, A., L. Varona, and E. Lopez de Maturana. 2008. TM Threshold Model. Accessed Oct. 26, 2011. http://snp.toulouse.inra. $\mathrm{fr} /$ alegarra/manualtm.pdf.

Liu, Z., J. Jaitner, F. Reinhardt, E. Pasman, S. Rensing, and R. Reents. 2008. Genetic evaluation of fertility traits of dairy cattle using a multiple-trait animal model. J. Dairy Sci. 91:4333-4343.

Mäntysaari, E., and L. D. Van Vleck. 1989. Estimation of genetic parameters for production and reproduction in Finnish Ayrshire cattle. J. Dairy Sci. 72:2375-2386.

Miglior, F., B. L. Muir, and B. J. Van Doormaal. 2005. Selection indices in Holstein cattle of various countries. J. Dairy Sci. 88:12551263

Mitchell, R. G., G. W. Rogers, C. D. Dechow, J. E. Vallimont, J. B. Cooper, U. Sander-Nielsen, and J. S. Clay. 2005. Milk urea nitrogen concentration: Heritability and genetic correlations with reproductive performance and disease. J. Dairy Sci. 88:4434-4440.

Muir, B. L., J. Fatehi, and L. R. Schaeffer. 2004. Genetic relationships between persistency and reproductive performance in first-lactation Canadian Holsteins. J. Dairy Sci. 87:3029-3037.

Oltenacu, P. A., A. Frick, and B. Lindhé. 1991. Relationship of fertility to milk yield in Swedish cattle. J. Dairy Sci. 74:264-268.

Pérez, Q. G., and G. M. Gómez. 2009. Genetic and environmental factors affecting productive performance in a Brown Swiss herd in the tropics. 2. Relationship between calving interval and milk yield. Revista Cientifica 19:77-83.

Pryce, J. E., M. P. Coffey, S. Brotherstone, and J. A. Woolliams. 2002. Genetic relationships between calving interval and body condition score conditional on milk yield. J. Dairy Sci. 85:1590-1595.

Raheja, K. L., E. B. Burnside, and L. R. Schaeffer. 1989a. Heifer fertility and its relationship with cow fertility and production traits in Holstein dairy cattle. J. Dairy Sci. 72:2665-2669.

Raheja, K. L., E. B. Burnside, and L. R. Schaeffer. 1989b. Relationships between fertility and production in Holstein dairy cattle in different lactations. J. Dairy Sci. 72:2670-2678.

Tanner, M. A., and W. H. Wong. 1987. The calculation of posterior distributions by data augmentation. J. Am. Stat. Assoc. 82:528540 .

Tiezzi, F., C. Maltecca, M. Penasa, A. Cecchinato, Y. M. Chang, and G. Bittante. 2011. Genetic analysis of fertility in the Italian Brown Swiss population using different models and trait definitions. J. Dairy Sci. 94:6162-6172.

Utrera, A. R., R. C. C. Robles, J. V. R. Fernández, and J. L. Lagunes. 2010. Estimation of genetic parameters for fertility traits in Brown Swiss cattle under subtropical conditions of Mexico. Vet. Méx. 41:117-129.

VanRaden, P. M., A. H. Sanders, M. E. Tooker, R. H. Miller, H. D. Norman, M. T. Kuhn, and G. R. Wiggans. 2004. Development of a national genetic evaluation for cow fertility. J. Dairy Sci. $87: 2285-2292$

Veerkamp, R. F., E. P. C. Koenen, and G. De Jong. 2001. Genetic correlations among body condition score, yield, and fertility in first-parity cows estimated by random regression models. J. Dairy Sci. 84:2327-2335

Zink, V., M. Štípková, and J. Lassen. 2011. Genetic parameters for female fertility, locomotion, body condition score, and linear type traits in Czech Holstein cattle. J. Dairy Sci. 94:5176-5182. 